\title{
California's Response to the Status of Gig Workers with Disabilities: An Update
}

\author{
Peter Blanck ${ }^{1} \cdot$ Paul Harpur ${ }^{2}$ \\ Accepted: 7 November 2020 / Published online: 30 November 2020 \\ (c) The Author(s), under exclusive licence to Springer Science+Business Media, LLC part of Springer Nature 2020
}

In a recent JOOR article [1], authors Harpur and Blanck examined gig work for people with disabilities, and we write with an important update triggered by this month's election and related developments.

Gig work is typically performed independently, without protections afforded employees such as the chance to purchase benefits or receive the protections of wage regulations, occupational health and safety rules, and antidiscrimination laws. While gig workers may potentially benefit from flexible work schedules and conditions, their work situations are often precarious [2], and the global pandemic has further complicated their shaky position.

As the rates of gig workers with disabilities rise, some have tried to provide them employment-like protections. A recent example, California State Assembly Bill 5, effective 1 January 2020, deemed people providing labor or services for remuneration, such as gig workers, to be employees rather than independent contractors [3].

On election day this month, however, the people of California voted to overturn Assembly Bill 5 by approving California Proposition 22, the "App-Based Drivers as Contractors and Labor Policies Initiative" [4]. The proposition defines app-based transportation (rideshare) and delivery drivers, such as those for Uber, Lyft, and DoorDash, as independent contractors. Proposition 22 generally did not affect how the prior law was to be applied to other types of workers [4-6]. But, as one commentator has noted, "A defeat of the proposal would have emboldened other localities to

A comment to this article is available at https://doi.org/10.1007/ s10926-020-09937-4.

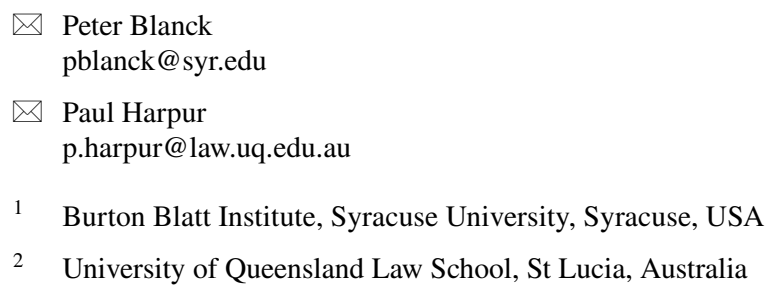

2 University of Queensland Law School, St Lucia, Australia

approach the issue in the same way that California had, while its victory is likely to entrench the status quo." [7].

California's status as "a bellwether for the gig economy" [8], and the status of Proposition 22, have indeed been influencing regulation in the United States and abroad [6]. In Massachusetts, the state Attorney General had, pre-election, sued to enforce a 2004 state law that she says requires Uber and Lyft to treat their drivers as employees. The California proposition outcome will likely influence whether and how the conflict develops outside the judicial system [9]. In New York, the day after the election, an Uber driver filed a class action in federal court alleging that Uber drivers should be classified as employees rather than independent contractors [10]. And the dispute is playing out in various ways in other states, including Oregon, Washington, New Jersey, and Illinois [11].

A new national Rehabilitation Research and Training Center on Disability Inclusive Employment Policy ("DIEP RRTC") has recently opened to address issues like those raised here [12]. Over the next five years it will implement data-driven studies to support increased employment opportunity for people with disabilities. One such study, proposed by Professors Lisa Schur, Douglas Kruse, and their colleagues at Rutgers University, will now examine the impact of California's Proposition 22 on people with disabilities.

It is unclear how Proposition 22 will affect increases in averages for pay, benefits, and job retention for gig workers with disabilities. To promote Proposition 22's passage, some companies using app-based drivers had said they would offer new health insurance protections for their drivers working more than $15 \mathrm{~h}$ per week, minimum mileage reimbursement rates, and occupational accident insurance coverage [6]. Determining whether and how these benefits play out will be one of the tasks for the new Center. Certain gig workers may come to occupy a hybrid, or third, status between employees and independent contractors. As suggested by Wilma Liebman, former chair of the National Labor Relations Board, 
they may become a new group of "dependent contractors" [13].

At this thirtieth year of the ADA in the United States, amid the pandemic, there is growing recognition that people with disabilities have the right to engage in all forms of work opportunity on an equal basis with others [14]. The DIEP RRTC will further explore the ways in which emerging work arrangements present barriers or opportunities for people with disabilities.

\section{References}

1. Harpur P, Blanck P. Gig workers with disabilities: opportunities, challenges, and regulatory response. J Occup Rehabil. 2020. https ://doi.org/10.1007/s10926-020-09937-4.

2. Schur L, Kruse D. Disability and precarious work. In: Oxford handbook on the sociology of disability. Oxford: Oxford University Press; forthcoming 2021.

3. California Legislative Information. Assembly Bill 5. Worker status: employees and independent contractors. http://leginfo.legis lature.ca.gov/faces/billTextClient.xhtml?bill_id=201920200AB5. Accessed 5 Nov 2020

4. California General Election November 3, 2020. Official Voter Information Guide. PROP 22-exempts app-based transportation and delivery companies from providing employee benefits to certain drivers. Initiative statute. https://voterguide.sos.ca.gov/ propositions/22/. Accessed 5 Nov 2020.

5. California proposition 22, app-based drivers as contractors and labor policies initiative (2020). In: BallotPedia. https://ballotpedi a.org/California_Proposition_22,_App-Based_Drivers_as_Contr actors_and_Labor_Policies_Initiative_(2020). Accessed 5 Nov 2020.

6. Rana P. California voters exempt Uber, Lyft, DoorDash from reclassifying drivers: ballot measure lets ride-hailing and food-delivery companies sidestep state labor law. In: Wall Str J. 4 Nov 2020. https://www.wsj.com/articles/california-voters-exemp t-uber-lyft-doordash-from-having-to-reclassify-drivers-11604 476276 ? st=plrts mylf2euq27\&reflink=article_email_share. Accessed 4 Nov 2020.

7. Mak A. Uber and Lyft got the result they wanted on election night. In: Slate. 4 Nov 2020. https://slate.com/technology/2020/11/propo sition-22-california-uber-lyft.html. Accessed 5 Nov 2020.

8. Marshall A. With $\$ 200$ million, Uber and Lyft write their own labor law. In: WIRED. 4 Nov 2020. https://apple.news/AZ27h Ls6gQ6q9nCpqXiiKRg. Accessed 5 Nov 2020.

9. Vaccaro A. Uber and Lyft are in an election day showdown with California. Massachusetts might be next. In: Boston Globe. 1 Nov 2020. https://www.bostonglobe.com/2020/11/01/metro/uber-lyftare-an-election-day-showdown-with-california-massachusettsmight-be-next/. Accessed 5 Nov 2020.

10. Angell M. Uber hit with new wage suit in New York. In: Law360. 4 Nov 2020. https://www.law360.com/amp/articles/1325706. Accessed 5 Nov 2020.

11. Lee D. Uber and Lyft in driving seat to remake US labour laws. In: Finan Times. 5 Nov 2020. https://www.ft.com/content/78e61 9f4-fabe-4077-a51a-491e24492263. Accessed 5 Nov 2020.

12. Blanck P. Disability inclusive employment and the accommodation principle: emerging issues in research, policy, and law. $\mathbf{J}$ Occup Rehabil. 2020. https://doi.org/10.1007/s10926-020-09940 $-9$.

13. Weber L. What if there were a new type of worker? Dependent contractor. In: Wall Str J. 28 Jan 2015. https://www.wsj.com/artic les/what-if-there-were-a-new-type-of-worker-dependent-contr actor-1422405831. Accessed 5 Nov 2020.

14. Blanck P. Disability law and policy. New York: Foundation Press; 2020.

Publisher's Note Springer Nature remains neutral with regard to jurisdictional claims in published maps and institutional affiliations. 